https://doi.org/10.52058/2786-5274-2021-2(2)-231-245

Юлдашев Олексій Хашимович доктор юридичних наук, професор, завідуючий кафедрою господарського та трудового права, МАУП, вул. Фрометівська, 2, м. Київ, 03039,тел.: (044) 490-95-00, e-mail: youldashev_a@ukr.net, https://orcid.org/0000-0002-6624-3481

\title{
ЧИ ПОТРІБЕН УКРАЇНІ НОВИЙ ПРЕЗИДЕНТСЬКИЙ УНІВЕРСИТЕТ
}

\author{
Президент в основу розвитку поклав потужну зброю, \\ яка здатна змінити світ - це освіта. \\ Президентський університет - ие стратегічний образ того, \\ щз ми повинні закладати в сучасну вищу освіту, науку, інновації та \\ розвиток суспільства. Можу з упевненістю сказати, що в Україні \\ починають формуватися професії, які створять нову хвилю інновачій" \\ (Міністр освіти і науки України).
}

Анотація. Освіта, з позицій суспільства, $є$ основним засобом розвитку гуманістичної сутності людини. Це по-перше. По-друге, суспільство, держава забезпечує соціальний захист населення від безробіття шляхом надання освітніх послуг, підвищення його конкурентоспроможності на ринку праці. По-трете, відбувається задоволення потреб суспільства в продуктивній силі. Звичайно ж, щоб освіта стала такою цінністю, необхідно створити в суспільстві достатньо конкурентні умови для використання цієї сили. Інакше будемо формувати соціальний капітал для інших країн. Наявність згаданих умов необхідно для боротьби з міграцією, втратою «робочих рук», «витоком мізків». I ще важливий аспект державно-громадської цінності освіти. Вона є (у всякому разі, повинна бути) джерелом інноваційного розвитку економіки, інформатизації суспільства. Для того, щоб освіта стала такою, потрібна не просто їі модернізація і / або інтеграція в європейський, світовий освітній простір. Необхідні нові підходи, перехід від традиційного підходу до інноваційної освіти, що забезпечує розвиток творчих здібностей, націленість на пошук і використання інновацій як в змістовному наповненні навчальних програм так і в засобах навчання.

Метою дослідження, результати якого викладені в даній статті, є розробка (на концептуальному рівні) моделі управління якістю освіти і науки, концепції їх реформування. Вищезазначена концепція може інтерпретуватися як одна 3 умов вирішення найважливішої державної проблеми - прогресуючого економічного і технологічного відставання України в області інновацій від високорозвинених держав. 3 усіма наслідками економічного і політичного характеру. Не менш 
важливою проблемою, вирішення якої також залежить від ефективності, якості і прозорості вищої освіти в Україні, є проблема забезпечення сталого розвитку. Відомо, що катастрофи людство уникне через створення нешкідливих для біосфери ноотехнологій. Саме на це повинно бути спрямований потенціал освіти і науки України.

Авторами дослідження, результати якого подано в цій статті, розроблені і концепція освітньої діяльності, і проекти рішень найбільш важливих проблем. Це внутрішні і зовнішні проблеми життєдіяльності нашої держави. До внутрішніх, найбільш важливим, першочерговим ми відносимо дві проблеми: 1) мінімізація корупції в органах державної влади, зростання ефективності економічного управління і 2) судова реформа. На вирішенні цих проблем наполягають і громадяни країни, і наші зарубіжні партнери. Від розв’язання цих проблем залежить не тільки успішність країни (прихід зовнішніх інвестицій, підняття рівня життя людей), але i, скажемо прямо, іiі виживання. Щодо зовнішніх проблем, то найбільш важливими $\epsilon$ : повернення окупованих територій, забезпечення безпеки, суверенітету і цілісності України.

Підходи до кардинального вирішення внутрішніх і зовнішніх проблем, що пропонуються нами - це низка тем, які могли б викладатися в рамках напрямів підготовки студентів університету майбутнього.

Ключові слова: освіта, гуманістична сутність людини, концепція освітньої діяльності, проекти рішень проблем, внутрішні i зовнішні проблеми життєдіяльності держави; мінімізація корупції в органах державної влади, зростання ефективності економічного управління; судова реформа.

Yuldashev Alexey Khashimovich Doctor of Law, Professor, Head of the Department of Economic and Labor Law, IAPM, st. Frometivska, 2, Kyiv, 03039, tel .: (044) 490-95-00, e-mail: youldashev_a@ukr.net, https://orcid.org/0000-0002-6624-3481

\section{ABOUT THE CONCEPT OF THE PRESIDENTIAL UNIVERSITY OF THE FUTURE}

Abstract. Education, from the standpoint of society, is the main means of developing the humanistic essence of man. This is the first. Secondly, society, the state provides social protection of the population from unemployment by providing educational services, increasing its competitiveness in the labor market. Third, society's needs for productive power are being met. Of course, for education to become such a value, it is necessary to create in society sufficiently competitive conditions for the use of this force. Otherwise we will form social capital for other countries. The presence of these conditions is necessary to combat migration, loss of "labor", "brain drain". And another important aspect of the state and public value of education. It is (at least, should be) a source of innovative economic development, informatization of society. In order 
for education to become such, it is necessary not just to modernize and / or integrate it into the European, world educational space. New approaches are needed, the transition from the traditional approach to innovative education, which ensures the development of creative abilities, the focus on finding and using innovations both in the content of educational programs and in teaching aids. The purpose of the study, the results of which are presented in this article, is to develop (at the conceptual level) a model of quality management of education and science, the concept of their reform. The above concept can be interpreted as one of the conditions for solving the most important state problem - the progressive economic and technological backwardness of Ukraine in the field of innovation from highly developed countries. with all the consequences of economic and political nature. An equally important issue, the solution of which also depends on the efficiency, quality and transparency of higher education in Ukraine, is the problem of ensuring sustainable development. It is known that mankind will avoid a catastrophe by creating harmless to the biosphere nootechnologies. This is what the potential of education and science of Ukraine should be aimed at. The authors of the study, the results of which are presented in this article, developed both the concept of educational activities and draft solutions to the most important problems. These are internal and external problems of life of our state. To the internal, the most important, priority we include two problems: 1) minimization of corruption in public authorities, increasing the efficiency of economic management and 2) judicial reform. Both the citizens of the country and our foreign partners insist on solving these problems. The solution to these problems depends not only on the success of the country (the arrival of foreign investment, raising the living standards of the people), but also, frankly, its survival. As for external problems, the most important are: the return of the occupied territories, security, sovereignty and integrity of Ukraine. Approaches to the cardinal solution of internal and external problems offered by us are a number of subjects which could be taught within the directions of preparation of students of university of the future.

Keywords: education, humanistic essence of the person, the concept of educational activity, projects of the decisions of problems, internal and external problems of vital activity of the state; minimization of corruption in public authorities, increasing the efficiency of economic management; judicial reform.

Постановка проблеми. Для виявлення проблеми, яка $\epsilon$, згідно до теорії системного аналізу, різницею між бажаним (цільовим) і фактичним (наявним) станами, сформулюємо бажані цілі освіти i науки. Почнемо 3 визначення значущості, важливості освіти i науки. Будемо розрізняти цю категорію (значущість, важливість освіти і науки) у традиційному сенсі і у новітньому, в авторському, тобто, як це пропонуємо ми. Освіта, у традиційному сенсі, є, 3 позицій суспільства, основним засобом розвитку гуманістичної сутності людини. Це по-перше. По-друге, суспільство, держава забезпечує соціальний захист 
населення від безробіття шляхом надання освітніх послуг, підвищення його конкурентоспроможності на ринку праці. По-третє, відбувається задоволення потреб суспільства в продуктивній силі. Говорячи про фактичний стан справ, слід зазначити, що в цілому, у тій чи іншій мірі, як кажуть «з горем навпіл» освіта досягає свого призначення у традиційному сенсі. Звичайно ж, щоб освіта стала хоча б у цьому сенсі ще більшою цінністю для держави, суспільства, необхідно створити хоча б достатньо конкурентні умови для використання вищезгаданої продуктивної сили. Інакше будемо формувати соціальний капітал для інших країн. Що, до речі, і відбувається зараз.

Тепер перейдемо до бажаного стану освіти i науки у новітньому, авторському сенсі, як то пропонуємо ми. Освіта, в авторському сенсі, має інтерпретуватися як засіб, одна з умов вирішення проблем як національного, так i міжнародного масштабу. Останні - це ті, що пов'язані зі світовими викликами. Про них пізніше. Що стосується проблем національного масштабу, то тут ми вирізнясмо дві найважливіші проблеми, які стоять перед державою Україна. Перша - це проблема прогресуючого економічного і технологічного відставання України в області інновацій від високорозвинених держав. Друга проблема полягає у організаційно-управлінському проваллі, а саме: у величезній корупції у владі і найнижчому за ефективністю (можна стверджувати від'ємному) рівні управління $з$ боку держави усіма економічними процесами. Звідси випливають усі негативні наслідки економічного і політичного характеру. До економічних наслідків належать низький рівень життя населення, міграція працездатної його частини для роботи в інших країнах, «витік мізків» тощо. До політичних наслідків низького рівня державного управління слід віднести наявні порушення територіальної цілісності України, подальші загрози її суверенітету, національній безпеці.

Чи стали освіта і наука дієвим засобом вирішення вищезазначених проблем, які стоять перед Україною? Звісно, ні, про що свідчить жахливий стан в країні, що стався як результат не вирішення, а навпаки, все більшого поглиблення згаданих проблем. Тому правомірною слід вважати постановку задачи реформування освіти i науки, а точніше, організації управління зазначеними об'єктами, розробку концепції цього реформування.

Аналіз останніх досліджень і публікацій. Програмні завдання в сфері освітньої політики та шляхи їх реалізації досліджували В. Андрущенко, Л. Губерский, С. Квіт, В.Кремень, А. Кузнецов, К. Левківський, В. Лутай, Г. Михайлюк, І. Совсун та інші. Методологічні аспекти організації і управління освітньою галуззю розкривають В.Аверьянов, К. Александров, В. Бабкін, В. Бакуленко, В. Бебик, В. Корсак, В. Тертичка, Ю. Шемшученко, Т. Stoner і інші.

Як показує аналіз робіт названих авторів та інших вчених, багато хто з них розглядав зв'язок розвитку освіти і науки 3 подальшим розвитком українського суспільства, переходом країни до інноваційної економіки, інформатизації суспільства, соціального розвитку. В практичному плані було прийнято рід 
законодавчих актів (Закон про вищу освіту та ін.), програмних документів (зокрема, Національна доктрина розвитку освіти України в XXI столітті). У той же час, досліджуючи вищезазначені питання, багато вчених обмежуються визначенням тих чи інших понять, класифікацій, принципів, називаючи отримані результати теорією. Якщо це так, то можна говорити про голод на розробки методичного рівня, які визначали б «ЩО» i, головне «ЯК» робити. Саме концептуальні положення здійснення певної діяльності (в даному випадку, освітньої) повинні містити відповіді на ці питання. На основі цих відповідей і повинен грунтуватися розвиток державної освітньої політики, яка може бути визначена як форма, а самі концептуальні положення інтерпретуватися як зміст організації освітньої (наукової) діяльності. Саме в симбіозі таких змісту і форми і могло б полягати «поєднання форми і змісту освітньої політики», здійснення «ефективного перерозподілу функцій і повноважень між центральними органами державної влади та навчальними закладами». А це те, що вимагає Національна доктрина розвитку освіти України в XXI столітті.

Метою дослідження, результати якого викладені в даній статті, була розробка (на концептуальному рівні) моделі організації управління якістю освіти і науки, концепції їх реформування.

Виклад основного матеріалу. 3 численних повідомлень у ЗМІ відомо, що в зараз в Україні планують створити президентський університет. На його будівництво (будівництво будівлі) планується витратити понад 7 млрд. Сформульовано освітні напрямки, за якими буде здійснюватися освітній процес Президентського університету. це: інформаційні технології; кібербезпека i штучний інтелект; нанотехнології; аерокосмічні технології; біотехнології і науки про здоров'я; енергетичні технології; глобалізація та міжнародні комунікації. Старт освітнього процесу, заявив міністр освіти і науки посилання - 1 жовтня 2023 року. Президентський університет, сказав далі він, повинен відповідати всім трендам навчання [1]. Разом 3 тим, можна тільки шкодувати, що питання створення університету пов'язується не 3 розробкою концепції його функціонування, а, перш за все, з будівництвом будівлі, відбором викладачів та абітурієнтів. Ми ж пропонуємо концепцію освіти нової якості, спрямовану на вирішення найважливіших проблем, що стоять перед країною. Але спочатку продовжимо розмову про недоліки підходу, до створення університету, що намітилися. Ми не згодні і з тим, що для занурення в світовий освітній простір досить почати навчання «або в третю тижні вересня або 1 жовтня», «як у всьому світі». Вважаємо, що коли кажуть про занурення в світовий освітній простір, то під останнім доцільно розуміти а) світові знання в той чи іншій предметній галузі, накопичені людством за всю його історію і б) знання найновіші. Мова повинна йти про освітні технології, що призводять до забезпечення доступу студентів до вищезазначених знань і генерування ними приросту знань. I це не гасла, не абстракція. Ми можемо запропонувати конкретні шляхи вирішення 
даного завдання. Далі. За великим рахунком, недостатньо навіть відповідати «всім трендам, які сьогодні $\epsilon$ в світі». Якщо говорити про освіту світового рівня, яка повинна бути визнаною всім світом, то, у буквальному сенсі, такої немає. $С$ загальновизнані зразки - Кембридж, Оксфорд, Гарвардський, Стенфордський університети, які вирізняються тим чи іншим параметрам. Освіта у вищих навчальних закладах завжди розглядалася як самоціль, яка чи не кожним закладом освіти вирішується автономно. На Заході, коли хочуть підкреслити престижність навчального закладу, то згадують видатні постаті, які навчалися там. Але ж що тут особливого? Деякі любителі статистики кажуть, що з окремих бійцівських клубів вийшло більше мільярдерів, ніж серед випускників самих відомих вишів. Вважаємо, що в сучасних умовах, умовах таких глобальних викликів як термоядерна війна, накопичення величезного арсеналу найнебезпечнішої зброї, в т.ч. хімічної, яка теж може винищити «все i вся» (яскравий приклад - нинішня пандемія - COVID-19), вичерпання не поновлювальних ресурсів, питної води на планеті, глобальне потепління тощо вимагають вже не автономності у навчанні, не освіти заради освіти, а координації освітньої діяльності в масштабах усього світу. Саме в цьому - в утвердженості необхідності спрямування освіти на вирішення проблем сучасності і міг би полягати УКРАЇНСЬКИЙ ОСВІТЯНСЬКИЙ ТРЕНД. Це якраз те, що ми могли б задати в сфері освіти і науки і це те, чого немає ще в світі. Світ рухається іншим шляхом, який ми позначаємо як в значній мірі формальний, бюрократичний. Яскравий приклад - Болонський процес. За задумом його авторів, цей процес направлений на «зближення і гармонізації систем освіти країн Європи в рамках Болонської угоди 3 метою створення єдиного європейського простору». Однак зазначене зближення відбувається, на нашу думку, у формальний спосіб: шляхом забезпечення єдності кваліфікацій, запровадження єдиних форм освітнього процесу, системи обліку й оцінки знань, впровадження кредитно-модульної системи тощо. Відомо, що "Лісабонська стратегія", складовою якої став Болонський процесс, мала на меті розв'язання проблеми "Свропейського парадоксу". Його сутність полягає у тому, що «світове лідерство Європи у виробництві інтелектуальних знань (освітніх послуг, наукових публікацій) не зумовлює домінантні економічні позиції в сучасному глобалізованому світі». Європа дедалі більше відстає в економічній конкуренції не тільки від США та Японії, а й особливо від Китаю, "азійських тигрів". Але ця ситуація не була виправлена. Болонський процес не спрацював. Насмілимося стверджувати, що зближати і гармонізувати системи освіти країн Європи, будувати Європейський простір вищої освіти потрібно було не тільки на основі запровадження Європейської рамки кваліфікацій, а й на суттєвому підвищенні якості освіти. Саме це призвело б до зростання якості інтелектуальної складової в економічній сфері. А роль саме цієї складової в економічній конкуренції невпинно зростає. 
Між тим, ніхто ні в Свропі, ні в нашій країні, у дійсності, не може відповісти на питання: а що ж таке ЯКІСТЬ ОСВІТИ, як визначити, виміряти якість підготовки фахівця. І ця безпорадність буде продовжуватися доти, доки на повному серйозі будемо обговорювати не дійсні, а псевдо проблеми, маніпулювати назвами кваліфікацій вищої освіти. Чи настільки приципова назва того чи іншого кваліфікаційного рівня - кандидат наук чи доктор філософії? Адже, коли ми говоримо про видатних вчених, то розрізняємо їх не за рівнем кваліфікації (доктор, професор, магістр), чи належністю до того чи іншого вузу, а за їх ВНЕСОК У ЗМЕНШЕННЯ ЕНТРОПІЇ, за їх науковими результатами. Саме за таблицю періодичних елементів нам відоме прізвище Менделєєв; Николу Теслу згадуємо і за розробку двигунів перемінного току, що підштовхнули промислову революцію, і дивлячись на будь-який радіо, телепристрій, які зараз нас оточують. Але ж мало хто знає, чи $є$ названі вчені (як і багато інших новаторів) професорами чи докторами наук. Не це важливо. До цих питань ми ще повернемось.

Зараз акцентуємо, що рівнятися на «світові зразки» в освіті і науці - є не дуже правильним. Було б правильніше нам самим задати свій національний тренд. І цей тренд міг би якраз і полягати, у визначенні «ЩО» і «ЯК» робити. Необхідно випереджати, а не безперервно (точніше, безуспішно) наздоганяти Захід, як ми це намагаємося робити на протязі всієї історії нашого існування. Розробка і реалізація власного тренда національної освіти в Україні - ось що має стати (це все до того) метою створення президентського університету.

Далі. Вважаємо, що не дуже доцільно i готувати студентів за перерахованими вище напрямками. Особливо, якщо мається на увазі використання існуючих традиційних технологій в процесі навчання. А це (намір використати традиційні технології) швидше за все так, оскільки про перехід до нових інформаційних навчальних технологій нічого не сказано. Будівля 3 мармуровими сходами, величезними аудиторіями - скоріш за все буде. Мабуть, навіть без сумнівів. Але технології все ж такі набагато важливіші. Тому університет майбутнього стане таким дійсно, якщо готувати в ньому будуть не за напрямками, які зазначені, і не за традиційними технологіями.

Чому саме підготовка студентів за зазначеними вище напрямками в університеті майбутнього не доцільна? Тому, що за цими напрямками підготовка вже ведеться і у дублюванні ії навряд чи $є$ сенс. Візьмемо для прикладу перший напрямок запропонованої підготовки - інформаційні технології. Відповідні проблеми, зокрема, проблему створення нового покоління високих наукоємних інформаційних технологій - інтелектуальних інформаційних технологій, успішно вирішує Міжнародний Центр інформаційних технологій і систем НАН України. Якість спеціалістів, які готуються за зазначеними напрямками визнана в країні і за кордоном. Що стосується галузевих інформаційних технологій - то за ними також чи не кожен вуз вже готує фахівців. Наприклад, Київський національний 
економічний університет (3 його філіями в областях) займається загальноекономічними, бухгалтерськими інформаційними технологіями; торговоекономічний університет (зі своїми філіями в Україні) - відає інформаційними технологіями в сфері торгівлі; кібербезпекою, проблемами штучного інтелекту; нанотехнологіями опікуються вищі навчальні заклади правоохоронних органів, політехнічні університети країни; аерокосмічними технологіями займається Національний авіаційний університет. Він уклав угоду про створення регіонального інноваційно-космічного кластера «Полісся». Учасники угоди активно співпрацюють у вирішенні завдань якісної підготовки фахівців i проведення наукових досліджень саме в галузі космічних систем і технологій. Що стосується біотехнологій, науки про здоров'я, енергетичних технологій - то це медичні університети, Інститут загальної енергетики НАН України, Навчально-науковий інститут енергетики. «ХПІ» визнано кращим технічним університетом України в світовому рейтингу; глобалізація та міжнародні комунікації - компетенція університету фінансів та міжнародної торгівлі, Інституту міжнародних відносин і т.д.

У діючих перерахованих i iнших вузах накопичено великий практичний досвід, склалися відповідні наукові школи, працюють кваліфіковані кадри. Чи $\epsilon$ сенс дублювати все це на рівні університету майбутнього? Тим більше, що в разі появи додаткових потреб в тих чи інших фахівцях, будь-який з перерахованих вузів може без труднощів набрати необхідну кількість студентів. Це не $\epsilon$ проблема. Перенести ж все це різноманіття в один університет, під «одну кришу» - це високий шанс на одержання ефекту Даннінга-Крюгера. Грандіозна задумка може обернутися не менш грандіозним провалом.

Все це обумовлює потребу у виявленні такого напрямку освітньої діяльності, за яким не дублювався б жоден вуз України. Це по перше. По друге, такий напрямок мав би бути вкрай потрібний для країни. 3 цією метою було б доцільно оголосити конкурс на розробку концепції освітньої діяльності президентського університету - університету майбутнього, як його називають.

У даній статті розглядається одна 3 можливих альтернатив такого роду концепції. За аналогією з Леніним, котрий виголосив 100 років тому фразу, що стала крилатою - «є така партія», наважимося заявити про те, що є такі напрями навчання, якими (як самостійними) не займається жодна установа вищої освіти (УВО) України. Разом з тим, вони (напрямки) мають бути не тільки, як можна так сказати, рідкісними, а й надзвичайно важливими, такими, від розвитку яких залежить доля нашої країни.

При визначенні напрямів освіти, які б відповідали зазначеним вимогам, ми виходили з нагальних і найскладніших проблем, а отже і цілей (цілі це дзеркальне відображення відповідних проблем) суспільства, а також з ідей їх вирішення, які також пропонуються нами. Згадані проблеми ми поділяємо на внутрішні i зовнішні, сьогоднішні і перспективні. До внутрішніх сьогоднішніх відносяться, 
перш за все, як вже частково зазначалось, технологічна відсталість виробництва, падіння, розвал економіки, зубожіння населення, масштабна трудова міграція, відтік «мозків» тощо. Причина цих перерахованих (внутрішніх сьогоднішніх) проблем полягає тільки в одному - неякісності, непридатності (для переходу на сучасні ринкові умови господарювання) ДІЮЧОЇ ОРГАНІЗАЦІЇ УПРАВЛІННЯ, зокрема, державної виконавчої влади - міністерств і відомств. Економістів, юристів у нас (да і у світі) готовлять пре достатньо. Але ж економіка - це, образно кажучи, вчення про ефективність, яка, в свою чергу, є результатом, свого роду оцінкою якісності економічного управління, його ОРГАНІЗАЦІЇ. Право (законодавство) може закріплювати «цементувати» будь-яку організацію. I якісну, і неякісну. А хто ж тоді відповідає за ЯКІСНІСТЬ організації управління, управлінської діяльності? Ніхто. Стверджуємо, що ключовими питаннями питаннями побудови якісної організації, побудови ефективного некорупційного управління як самостійним напрямом освіти ніхто майже не займається. А саме це і є головним у забезпеченості якісності і економічного управління, і правової, юридичної форми як такої, а отже і економіки у цілому. Організація управління це, з однієї сторони - слабка ланка управління, а з другої вирішальна, замінивши яку можна забезпечити якісну роботу усього ланцюга. На практиці чи не в кожному міністерстві, відомстві діють центри реформування, вдосконалення управління, по суті, його організації. Цій же задачі присвячено функціонування центрів реформування, що створені у складі Кабінету Міністрів, Президента України. Однак вони діють, по перше, автономно, умовно кажучи, кустарним способом. По друге, відсутня методологія, відповідь на питання «як» це робити. Отже, робота центрів реформування, вдосконалення управління ніяк не координується, ні методологічно, ні організаційно. Хоча центри реформування Кабінету Міністрів, Президента України могли б здійснювати такого роду координацію. Але вони ніяк не пов'язані зі згаданими галузевими утвореннями i теж діють самі по собі. Результат такого реформування, вдосконалення вочевидь. Топчемося на місці, щоб не сказати деградуємо (в економічному сенсі), корупція у владі зростає, державний бюджет усі роки незалежності розкрадається у дуже значних масштабах, що постійно зростають.

Неефективність, можна стверджувати, відсутність належного економічного управління, ефективних управлінських технологій, а також організаційних умов, які б виключали б корупцію у владних структурах - i обумовлюють потребу у запровадженні вищезгаданого напряму освіти - ОРГАНІЗАЦІЙНЕ ПРОЕКТУВАННЯ засобів державного управління. Ці, сьогоднішні проблеми $\epsilon$ водночас і перспективними.

Другий напрямок підготовки (мається на увазі вже вирішення зовнішніх проблем) - це ВДОСКОНАЛЕННЯ ОРГАНІЗАЦІЇ СВІТОВОГО ПРАВОПОРЯДКУ. Загальновизнаним $є$ той факт, що існуюча організація світопорядку, яка побудована по закінченню другої світової війни, у сучасних 
умовах, нинішніх викликах не є ефективною. Вона (існуюча організація) не може досягти своїх цілей - забезпечення світової безпеки. Необхідність реформування існуючої організації світопорядку теоретично давно обгрунтована. На зміну теорії міжнародних конфліктів, яка грунтувалася на конфлікті ідеологій, висунуто концепцію конфлікту релігій, культур, цивілізацій. (Самуель Гантінгтон та ін.). Остання концепція виходить 3 першочерговості вищезазначених факторів у посиленні агресії у світі, що може призвести до термоядерної війни.

Більш ніж переконливим фактом необхідності докорінної зміни, вдосконалення організації світового правопорядку, є ситуація що склалася на сьогодні в Україні - коли Російська Федерація анексувала Крим і окупувала Донбас. Ніякі заходи, що приймаються існуючими міжнародними інститутами забезпечення безпеки не вирішують (i не здатні в принципі вирішити) безпрецедентну практику порушення світового правопорядку. Саме тому мова має йти не про часткове вдосконалення організації світового правопорядку, а про моделювання принципово іншого, кардинальну зміну існуючого.

Таким чином, йдеться про два напрямки освіти: I. ОРГАНІЗАЦІЙНЕ ПРОЕКТУВАННЯ засобів державного управління і II. ВДОСКОНАЛЕННЯ ОРГАНІЗАЦІЇ СВІТОВОГО ПРАВОПОРЯДКУ.

Це щодо сьогоднішніх внутрішніх $\mathrm{i}$ зовнішніх проблем. Але $\epsilon$, як зазначалось, і перспективні цілі розвитку освіти і науки. Перспективні не в сенсі віддаленості їх досягнення (робота над ними потрібна вже сьогодні і зараз), а в плані відповіді, що ми будемо робити, коли побудуємо не корупційну, ефективну організацію управління. Зрозуміло, що цей процес - процес побудови організації управління - нескінченний. Відомо, що вдосконаленню немає меж. Крім того нові виклики, нові проблеми потребують адекватних відзивів. Але $є$ i дійсно перспективні цілі розвитку освіти і науки. Коротко скажемо про них - про перспективні, більш високі цілі. Це: 1) побудова в Україні інформаційного суспільства, суспільства знань (інакше країна залишається сировинним придатком у «золотого мільярда», а в кінцевому рахунку, як випливає з висновків закордонних аналітичних центрів, - нам загрожує розвал і зникнення 3 карти Землі. Як відомо, є вже сценарій цього. I не один; 2) сталий розвиток, тобто це екологія, знову таки, виживання.

Особливу значущість набуває завдання побудови в Україні суспільства знань у сучасний період - в період Четвертої промислової революції (Індустрія 4.0), яка передбачає новий підхід до виробництва, заснований на масовому впровадженні інформаційних технологій в промисловість, масштабній автоматизації бізнеспроцесів і поширенні штучного інтелекту. Е.Тоффлер називає головні етапи розвитку, еволюції людей з моменту їх відділення від тваринного світу, «хвилями» [2]. Постіндустріальне суспільство він відніс до третьої «хвилі».

Щодо побудови в Україні суспільства знань, переходу до Індустрії 4.0 (суспільства третьої «хвилі»), то засобом цього в нашій країні мають стати 
реформовані на наукових засадах українська освіта і наука, а основою стратегії реформування, розвитку освітньо-наукового комплексу - концепція, що пропонується.

Паралельно могло б розвиватися i господарське законодавство, що регламентує виробничо-господарські відносини. Відповідні господарсько-правові норми мають бути спрямовані на стимулювання розвитку інноваційних ресурсів, які у подальшому будуть визначати дійсну вартість підприємств на ринку. Як свідчить сучасна виробнича практика, саме інновації, новітні технології, об'єкти інтелектуальної власності, створені й використовувані на підприємстві - це сховані економічні резерви. Ці резерви, інтелектуальний потенціал - мають стати найважливішою можливістю збільшення ринкової вартості та конкурентноздатності підприємства.

Стосовно реформування вищезазначеного освітньо-наукового комплексу. Система підготовки як фахівців вищої освіти так і вищої кваліфікації безнадійно застаріла. Щодо перших (фахівців з вищою освітою). Випускники вузів виходять з установи вищої освіти (УВО) з дипломом і набором формальних знань. Чому формальних? Тому що, як правило, вони вже на виході випускника є застарілими. Диплом залишається, а от знання все в більшій мірі втрачають цінність в зв'язку 3 експоненціальним прогресом в якості технологій. Це свідчить про те, що в освіті потрібно щось інше - те, чому в університеті традиційного типу не вчать. Трохи втішитися може лише тим, що на Заході університети теж критикують рівно за те ж саме, причому дістається і найпрестижнішим навчальним закладам, таким як Оксфордський, Гарвардський, Стенфордський університети. Світ змінюється так швидко, що не можна 3 точністю визначити, які саме знання знадобляться сьогоднішнім студентам через декілька років. Дуже проблемно гарантувати, що та чи інша інформація не втратить своєї актуальності.

Якщо це так, то, можливо і не слід прагнути зробити це. В рамках концепції реформування, в якості альтернативи традиційному процесу навчання, пропонуємо якісно інший підхід до підготовки фахівців. Це інноваційний, так званий компетентнісний підхід, сутність якого в тому, що в процесі навчання акцент робиться не стільки на засвоєння суми відомостей (знань), скільки на напрацювання таких умінь, які дозволяли б майбутнім фахівцям визначати свої цілі, виявляти і аналізувати проблеми, розробляти альтернативи їх вирішення, приймати рішення і діяти в типових і нестандартних ситуаціях.

Основна ідея цього підходу полягає в тому, що головним результатом освіти стають не окремі знання, вміння i навички, а ЗДАТНІСТЬ і ГОТОВНІСТЬ людини до ефективної та продуктивної діяльності. Підкреслимо, що знання це лише складова компетентності, але самі по собі вони ще не роблять людину компетентним. Компетентність - це характеристика, що дається людині в результаті оцінки ефективності /результативності його дій, спрямованих на вирішення певного кола значущих для спеціалістів певної галузі завдань/ 
проблем.

Компетентнісний підхід забезпечує розвиток творчих здібностей, націленість на пошук і використання інновацій. Він полягає як в змістовному наповненні навчальних програм так і у вдосконаленні процесу навчання.

Стосовно першого (змістовного наповнення навчальних програм). Безумовно, ідея надання студенту найактуальнішої, найсвіжішої, найважливішої інформації не відкидається. Навпаки, саме з такою інформацією ми пропонуємо пов’язати категорію ЯКОСТІ ОСВІТИ. До речі, бюрократи від освіти правильно сформулювавши завдання - підвищити іiі якість, так і не сказали, а що це таке. Ні законодавство про освіту, ні численні програмні документи, стратегії, місії, які розробляють Міносвіти і науки, а в основному, НАЗЯВО (Національне агентство забезпечення якості освіти) - не дають чітку конструктивну відповідь, ЩО ТАКЕ ЯКІСТЬ ОСВІТИ. Проте масштабно розписується найулюбленіший предмет бюрократії - КОНТРОЛЬ - його форми, види, структури для реалізації. Створений новий спеціальний орган - Національне агентство забезпечення якості вищої освіти за Законом про вищу освіту «перебирає» на себе всі основні функції контролю. Що ж стосується якості освіти - то цю сутність (якість освіти) бюрократи віддали на відкуп «низам» - вузам, викладачам. Нехай там вони розбираються, займаються якістю освіти. Для всього цього звели в культ «університетську автономію». Самі ж бюрократи були і залишаються лише контролерами, але ніяк не методологами (хоча вони не без претензій на це). Але вузам, як і викладачам теж не дуже потрібна дійсна якість в освіті. Вузам цікава університетська автономія лише 3 точки зору самостійного розпорядження фінансами і нічим більше. Для самозбереження вузи намагаються «зробити свій рейтинг» шляхом заповнення численних паперів, що безперервно надходять від бюрократів-контролерів, але ніяк не впливають на якість освіти. Перевіряючі (від контролерів) також не обтяжують себе якістю. Вони можуть лише допомогти (якщо їх правильно зустріти i проводити) заповнити численні форми, запропоновані «зверху». А викладачам що - написав собі конспект років двадцять тому, і з того часу теж тільки «контролюй», але вже ... студента.

Основні ідеї вдосконалення змісту навчальних програм, по суті, забезпеченню дійсної якості освіти, полягають, як було сказано, перш за все, в тому, що ці програми мають складатися ПОВНІСТЮ 3 новітніх положень, наукових розробок у відповідній предметній сфері життєдіяльності. Саме таку інформацію зможуть забезпечити розвинена наука. Як? За рахунок реформування організації науково-дослідного процесу, а також процесу атестації фахівців вищої кваліфікації (кандидатів наук, докторів наук). Неважливо, як називати фахівця вищої кваліфікації - кандидатом наук або доктором філософії, доктором наук. Головне, що він вчений. А таким здобувач кваліфікації вченого зможе бути визнаним тільки, скажімо, через півроку після оприлюднення одержаних результатів (час для встановлення зворотного зв’язку), в т.ч. (а, можливо,і перш за все) через їх використання у навчальних програмах, після найширшого 
ознайомлення з одержаними науковими результатами усіх студентів, усіх інших бажаючих з усього світу. Передбачається створення автоматизованого Банку наукових результатів, в якому в автоматичному режимі буде відбуватися перевірка ступеню новизни цих результатів, а також передача їх у навчальнодослідні центри (навчально-дослідний центр). Чому саме центр, а не центри (УВО, НДІ - науково-дослідний інститут)? А тому, що ми впевнені - мережі автономних навчальних (да і наукових) закладів - вже давно вичерпали себе перетворилися із засобу корисного для людей, споживачів освітніх послуг,інновацій - у засіб користі «для себе». Ці заклади живуть своїм життям, а первісне їх призначення давно стало навіть не другорядною задачею. Тому вони це позавчорашній день. У той же час бурхливі глобальні зміни навколишнього світу, з однієї сторони, поява Всесві́тнього павутиння (Всесві́тньої мережі) Інтернету, а також Покоління Z, що не уявляє життя без інтернету, народилося вже зі сторінками у соцмережах і задає запитання не вчителю, а Гуглу чи Siri - 3 іншої - створили необхідність і актуальність переходу до принципово інших сучасних технологій навчання і розробки нововведень.

Щодо подальшої долі наукових результатів. Усі вузи, усі викладачі зобов’язані або включити і використовувати ці результати у навчальному процесі, або аргументувати відмову робити це. Таким чином здобувач наукового ступеню стане відомий світу як вчений вже не за папіром (дипломом), а саме за ті наукові результати, які він привніс у світ.

Саме такий порядок реформування процесу атестації кадрів вищої кваліфікації дозволить вирішити дві важливі задачи. По перше, це якість навчальних програм, навчального процесу. Ці програми, навчальні матеріали будуть уявляти собою за змістом набір останніх наукових досягнень (а це основна ознака якості навчального процесу, освіти).

Друга задача, на вирішення якої спрямована концепція реформування атестації - це якість самих наукових результатів. Недобросовісні здобувачі наукового ступеню завжди намагаються утаємничити свої наукові результати від широкої громадськості, провести дисертацію як секретне дослідження, захистити iii у закритій спецраді тощо. Звісно, що порядок, який пропонується, суттєво зменшить чисельність здобувачів за рахунок відсікання тих, хто йде в науку за дипломом, а не одержанням наукових результатів. А, водночас, підвищиться якість наукових результатів.

Відносно другого параметру якісної освіти - вдосконалення процесу навчання. За допомогою сучасних інформаційних технологій стає можливим залучення у навчальні програми, навчальний процес не тільки сучасні наукові результати, а й усі знання, накоплені людством за усі часи його існування. У найближчий час не будуть великим секретом технології, що використовувалися при побудові єгипетських пірамід або Стоунхенджу. В рамках авторської концепції оцінена потенційна можливість засвоєння і корисного використання 
знань накопичених людством (на сьогодні ступінь засвоєння i корисного використання знань накоплених людством складає менше одного процента). запропоновані організаційні параметри для управління даним процесом.

Стосовно «ЯК» вчити. Безумовна відмова від «знанієвого підходу», який зараз повсюдно (за деякими виключеннями) використовується і в школах, і у вишах. Згідно авторської концепції, основна увага в процесі підготовки фахівців повинна приділятися виробленню у студента здатності знаходити інформацію про нові продукти, технології, використовувати їі в практичній сфері, виявляти i реалізовувати можливості інноваційно-екологічного розвитку суспільства. При формуванні такої здатності основна увага повинна приділятися не тільки інформації про об'єкти пізнання (технології, процеси), а й засобам доступу до неї, понятійному апарату системного аналізу, умінням аналізувати ситуацію у відповідній предметній області (на підприємстві, в галузі, регіоні). Потрібно вміти виявляти дійсні проблеми і формулювати ідеї щодо їх вирішення. Тобто, мова йде про формування компетентності, вироблення творчого, проблемноорієнтованого підходу.

Висновки. Нинішній спосіб підготовки фахівців через систему відособлених, автономних структур - навчальних закладів добігає кінця. Нові глобальні виклики вимагають вже не автономності у навчанні, не освіти заради освіти, а підвищення якості і координації освітньої діяльності в національному вимірі, масштабах усього світу. У зв’язку з цим на питання: «Чи потрібен Україні новий президентський університет», ми даємо негативну відповідь. Український освітянський тренд міг би полягати в утвердженості необхідності спрямування освіти на вирішення проблем сучасності.

Вважаємо за доцільне розглядати освіту, вищу освіту як один із засобів вирішення найважливіших проблем, які стоять перед державою Україна. Стратегія розвитку освітньо-наукового комплексу України повинна бути спрямована на вирішення проблем підвищення якості освіти i науки, перетворення їх у засіб переходу до четвертої промислової революції. Цілі освітньої Стратегії - забезпечення накопичення креативного, високоякісного людського капіталу як головного драйверу налагодження виробництва інновацій, їх масової генерації - можуть бути реалізовані за допомогою авторської концепції реформування організації освіти і науки. При цьому найбільший ефект може бути досягнутий за умови функціонування (розвитку) цих сфер як взаємопов'язаних складових єдиної організації управління освітою i наукою. Якщо обидві ці складові представити у вигляді відповідних систем (а кожна система, згідно системного аналізу, може бути описана у термінах трійки (вхід, процес і вихід), то «вихід» науки (наукові результати) має бути пов'язаний з «входом» в освіту. А це навчальні програми, навчальні матеріали (освітянські стандарти). Навчальний процес має трактуватися як процес нарощування нових знань. Різниця між набутими знаннями і знаннями початковими, якими володів абітурієнт - складає 
той приріст, який має бути оцінений для визначення кваліфікації випускника бакалавр, магістр (доктор філософії).

На побудову системи навчання, нової якості спрямована нова освітня парадигма, концепція підвищення якості освіти, яку ми пропонуємо. В рамках цієї концепції сформульовано визначення якісної (інноваційної) освіти. Запропоновано конструктивні засоби для ОЦІНКИ іiї якості і розвитку, а також механізм побудови відповідної управляючої системи, що дозволяє нарощувати якість освіти і науки, забезпечує отримання синергетичного ефекту. Останнє (механізм побудови відповідної системи, що дозволяє нарощувати якість освіти і науки) потребує окремого розгляду, що ми і плануємо зробити у наступних публікаціях.

\section{Лimepamypa:}

1. В Украине создадут президентский университет будущего, - Зеленский // https://news.obozrevatel.com/politics/v-ukraine-sozdadut-prezidentskij-universitet-buduschegozelenskij.htm

2. Тоффлер Э. Третья волна/ Э.Тоффлер. М., ООО «Фирма Издательство АСТ», 1999, 784 с.

\section{References:}

1. V Ukraine sozdadut prezidentskij universitet budushhego, - Zelenskij [In Ukraine, a presidential university of the future will be created]. Retrieved from https://news.obozrevatel.com/ politics/v-ukraine-sozdadut-prezidentskij-universitet-buduschego-zelenskij.htm [in Ukrainian].

2. Toffler, Je. (1999). Tret'ja volna [The third wave]. Moscow: OOO «Firma Izdatel'stvo AST» [in Russian]. 